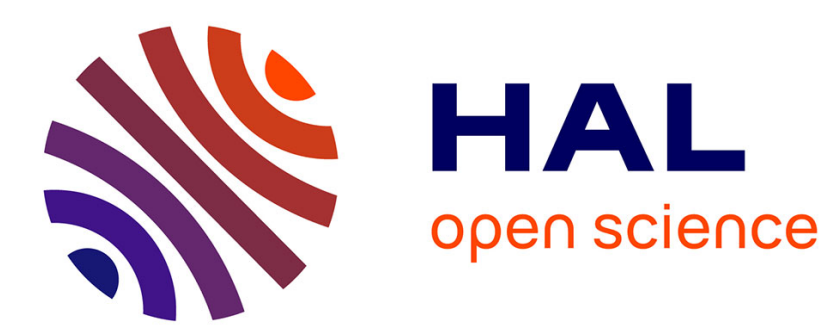

\title{
The use of directional traps for the assessment of short-term phenanthrene effects upon soil springtail communities
}

Frédéric Gass, Servane Gillet, Jean-François Ponge

\section{- To cite this version:}

Frédéric Gass, Servane Gillet, Jean-François Ponge. The use of directional traps for the assessment of short-term phenanthrene effects upon soil springtail communities. Environmental Pollution, 2006, 140 (2), pp.364-370. 10.1016/j.envpol.2005.06.027 . hal-00367089

\section{HAL Id: hal-00367089 \\ https://hal.science/hal-00367089}

Submitted on 17 Apr 2009

HAL is a multi-disciplinary open access archive for the deposit and dissemination of scientific research documents, whether they are published or not. The documents may come from teaching and research institutions in France or abroad, or from public or private research centers.
L'archive ouverte pluridisciplinaire HAL, est destinée au dépôt et à la diffusion de documents scientifiques de niveau recherche, publiés ou non, émanant des établissements d'enseignement et de recherche français ou étrangers, des laboratoires publics ou privés. 
1 The use of directional traps for the assessment of short-term phenanthrene

2 effects upon soil springtail communities

3

4 Frédéric Gass, Servane Gillet, Jean-François Ponge

5

6 Museum National d'Histoire Naturelle, CNRS UMR 5176, 4 Avenue du Petit-Chateau,

791800 Brunoy, France

8

9 Corresponding author: J.F. Ponge, tel. +33 1 60479213, fax +33 160465009 , e-mail:

10 jean-francois.ponge@wanadoo.fr

12 Abstract

13

14 Directional traps, both horizontal and vertical, were used to assess the

15 behavioural impact of phenanthrene application on soil springtail communities.

16 Avoidance was not detected. Rather, a vertical attraction of the dominant species,

17 Folsomia manolachei, was demonstrated, as well as a decrease in horizontal movements of Lepidocyrtus lanuginosus, another important species mainly captured at

19 the soil surface. Ecological consequences of the results are discussed.

20

21 Keywords: Phenanthrene; Springtails; Directional traps; Behaviour

1. Introduction

The assessment of environmental hazards is still mostly achieved through

26 laboratory tests using species which have been selected for the ease to obtain them in

27 high numbers (Dorn et al., 1998; Fountain and Hopkin, 2005). There is a need for field-

28 relevant methods which can be used to predict changes that may occur at the 
1 community level under the influence of a contaminant (Fent, 2003; Fountain and

2 Hopkin, 2004b). Field sampling along transects of increasing contamination has been

3 used for studying the impact of environmental hazards on soil animal communities

4 (Bengtsson and Rundgren, 1988; Erstfeld and Snow-Ashbrook, 1999; Fountain and

5 Hopkin, 2004a). Ecotoxicological tests and field monitoring of populations are reliable

6 methods for the assessment of contamination end-points, but they do not inform us

7 about the mechanisms in play and the way by which populations become

8 depauperated.

9

The toxicity and the bio-accumulation of pollutants have been well studied in soil animals (Hopkin et al., 1989; Crouau et al., 1999; Johnson et al., 2002), but still little is known about behavioural aspects, in particular the effects of pollutants on the movement of animals in terrestrial ecosystems (Yeardley et al., 1996; Michelozzi et al., 1997; da Luz et al., 2004). It has been shown that some springtail species are able to avoid contaminants while others, belonging to the same community, did not or even were attracted to them (Tranvik and Eijsackers, 1989; Filser et al., 2000; Chauvat and Ponge, 2002). Avoidance movement can be used by an animal to escape a pollutant, provided it can reach more or less rapidly a refuge (Shakir Hanna and Weaver, 2002), but attraction or paralysis might on the contrary entrap it in a toxic environment

20 (Eijsackers, 1978; Fábián and Petersen, 1994; Petersen and Gjelstrup, 1998). The choice of food is another important clue and, if as a general rule animals avoid toxic food (Visser and Whittaker, 1977; Filser and Hölscher, 1997; Michelozzi et al., 1997), definite attraction to harmful food items may sometimes be observed (Sadaka-Laulan et al., 1998). animals in patchy environments (Duelli et al., 1990). We suggest that they can be also used to follow horizontal as well as vertical movements of soil animal populations in the 
1 presence of contaminants, in particular hydrocarbons, the smell of which may act as a

2 behavioural signal, as this has been demonstrated with fungal odours (Bengtsson et

3 al., 1988, 1991; Hedlund et al., 1995). Avoidance of crude petroleum by earthworms

4 has been observed (Shakir Hanna and Weaver, 2002), but what happens in the case of

5 complex assemblages such as soil springtail communities? In an experimental study of

6 the effects of naphthalene application on the ground, Best et al. (1978) concluded that

7 the horizontal movement of arthropods was negatively affected by naphthalene and

8 that vertical movement was probable, although their sampling methods were

9 unappropriate to fully investigate the latter phenomenon. We thought that the

10 incorporation of horizontal and vertical directional traps in the soil could allow to

11 demonstrate the existence or inexistence of movements of invertebrate populations

12 when hydrocarbons are deposited at the ground surface. Phenanthrene was used,

13 being one of the main components of crude oil as well as of numerous industrial waste

14 products (Bouchez et al., 1996). It is also known for its toxicity and mutagenicity to a

15 wide range of organisms (Schirmer et al., 1998; Crouau et al., 1999; Landrum et al.,

16 2003).

17

\section{Material and methods}

Phenanthrene, $\mathrm{C}_{14} \mathrm{H}_{10}$, a weakly-soluble 3-cycle $\mathrm{PAH}\left(1.6 \mathrm{mg} \cdot \mathrm{L}^{-1}\right.$ at $15^{\circ} \mathrm{C}$ in water), was used in solid state, in the form of a fine white powder (purity 98\%) with moderate smell, purchased from Sigma-Aldrich Chemie GmbH (Steinheim, Germany).

The soil used for the experiment stemmed from a woodlot mainly comprised of oak [Quercus petraea (Mattus.) Liebl.] and hornbeam (Carpinus betulus L.) at the 26 inside of the Park of the Laboratory (Brunoy, France, $20 \mathrm{~km}$ South-East of Paris). It

27 was a black rendzina rich in clay $(28.2 \%)$ and organic carbon $(4.7 \%)$, with a near 28 neutral $\mathrm{pH}_{\mathrm{H} 20}(7.4)$ and a low $\mathrm{C} / \mathrm{N}(11.8)$ in the top $10 \mathrm{~cm}$ (Vannier, 1970). The humus 
1 form was an earthworm mull, called calcic Eumull according to Brêthes et al. (1995).

2 Detailed vegetation, soil and climate data can be found in Vannier (1970). Collembolan

3 communities living in the topsoil were described in Chauvat and Ponge (2002) and

4 Ponge et al. (2002). Seasonal variations were studied in Ponge (1973). The vertical

5 distribution of the main species and their food diets were analysed in Arpin et al.

$6 \quad(1980)$

7

In February 2004 around $300 \mathrm{~L}$ of soil were collected in the top $10 \mathrm{~cm}$ then homogenized over a plastic sheet before being distributed in 10 rectangular glass jars $60 \times 30 \times 30 \mathrm{~cm}$ (LxIxh). Before complete filling, two cylindrical (85x100 mm Øxh) and two rectangular (75x55x105 mm LxIxh) directional traps were positioned in each jar. The traps enclosed their own volume $\left(\mathrm{ca} .500 \mathrm{~cm}^{3}\right.$ ) of the same soil. They were made of polyvinyl chloride, one side being fitted with a $2 \mathrm{~mm}$ mesh plastic net, the opposite side with a $20 \mu \mathrm{m}$ mesh nylon gauze. Cylindrical traps were entirely buried into the soil, their upper part (covered with either plastic net or nylon gauze) being at $1 \mathrm{~cm}$ from the ground surface. They were positioned side by side by inverted pairs at $1 / 4$ length of the glass jars, centered under the area where phenanthrene was further applied.

Rectangular traps were postioned side by side by inverted pairs, with their upper part 1 $\mathrm{cm}$ above the ground level, the remaining $9.5 \mathrm{~cm}$ being buried. The side with either nylon gauze or plastic net was facing the area where phenanthrene was further applied. After complete filling of the experimental jars $(15 \mathrm{~cm}$ soil, $15 \mathrm{~cm}$ free space above the soil), they were transported to the laboratory, then let in darkness during a week in a chamber at constant temperature $\left(20^{\circ} \mathrm{C}\right)$. This incubation period was needed to let enough time for the animals to stabilize their vertical position according to species requirements and to acclimate to chamber conditions.

After the acclimation period, phenanthrene was applied in five randomly selected jars at the rate of $10 \mathrm{~g}$ per jar. The powder was applied as uniformly as 
1 possible over half the surface of each jar $(30 \times 30 \mathrm{~cm})$, thus amounting to $1.1 \mathrm{Kg} \cdot \mathrm{m}^{2}$.

2 Then the jars were randomly put on wood trays along both sides of the climate

3 chamber, randomization being effective on their horizontal and vertical position but also

4 on the orientation of the jars on the trays. Ten days after, the trap boxes were collected

5 then put in Berlese funnels, with the plastic net below, to extract microarthropods

6 (Edwards and Fletcher, 1971). Animals were preserved in 95\% ethyl alcohol until

7 identification.

8

Springtails were sorted then identified at the species level using Gisin (1960),

Zimdars \& Dunger (1994), Jordana et al. (1997), Fjellberg (1998), Bretfeld (1999), Hopkin (2000) and Potapov (2001).

Prior to statistical testing, data were analysed by correspondence analysis, a multivariate method which allows to discern most prominent trends in the data matrix (Greenacre, 1984). Although not purposed for experimental data, this method was used to avoid repeated testing of a meaningless number of variables, by focusing on those species or those population parameters which responded the best to the treatments. Active (main) variables were the species, none being discarded. Passive (additional) variables were the treatments, and population variables such as sample species richness and total abundance. Passive variables did not influence the calculation of factorial axes, but they were projected among species and samples in order to better interprete the significance of factorial axes. As in previous studies on soil collembolan communities (Ponge et al., 2003; Gillet and Ponge, 2004), each variable was standardized (mean 20 , standard deviation 1) and associated to a conjugate one $\left(x^{\prime}=40-x\right)$ in the search for possible gradients of global abundance. 
1 gaussian distribution of residues. Comparisons between control and phenanthrene jars

2 were achieved through unpaired t-tests, control and phenanthrene replicates being

3 independent.

4

5 3. Results

6

Table 1 shows mean values for species abundances and population parameters according to treatments. At first sight, no outward change in total abundance or species richness seemed to occur within the ten days of the experiment.

The projection of active and passive variables in the plane of the first two factorial axes of correspondence analysis $(13.7 \%$ and $23.2 \%$ of the total variance, respectively, thus totalling 36.9\%) (Fig. 1) showed that the main effect of the experiment was a contrast between rectangular traps used for detecting horizontal movements (inwards vs outwards) and cylindrical traps used for vertical movements (upwards vs downwards). This effect was trivial, since springtail assemblages of rectangular and cylindrical traps differered according to behavioural requirements of the species. Species which were projected on the east (positive) side of Axis 1 , such as Lepidocyrtus lanuginosus Gmelin (LLA), Sminthurinus aureus Lubbock (SAU), Onychiurus pseudogranulosus Gisin (OPS), Heteromurus major Moniez (HMA) and Monobella grassei Denis (MGR), could be considered typical of rectangular traps and thus as living at the surface in the conditions of our experiment, while those projected on the opposite side of the same axis, such as Micranurida sensillata Gisin (MSE),

24 Parisotoma notabilis Schäffer (PNO), Isotomiella minor Schäffer (IMI) and

25 Pseudosinella immaculata Lie-Pettersen (PIM) can be considered as living deeper in 26 the soil, since they were found preferentially in buried cylindrical traps. There was also

27 more specimens and more species in the traps used for capturing horizontal movements than for those used for vertical movements. 
However, less trivial was the difference between phenanthrene and control traps which was shown on the east side of Axis 1. Treatments 'P out' (phenanthrene outwards) and ' $\mathrm{P}$ in' (phenanthrene inwards) were projected nearer the origin of the axes (barycentre) than corresponding control treatments (' $\mathrm{C}$ out' and ' $\mathrm{C}$ in'). This means that phenanthrene seemed to decrease the contrast between 'horizontal' and 'vertical' traps. This was tested on L. lanuginosus, the most typical species of the 'horizontal' traps, which was also one of the most abundant springtail species in the studied population (Table 1). L. lanuginosus was, as expected, more abundant in 'horizontal' than in 'vertical' traps, both in the presence and in the absence of phenanthrene (Fig. 2), but the difference between 'horizontal' and 'vertical' traps was lessened by the application of phenanthrene $(t=-3.195, P=0.006)$.

Axis 2 revealed an opposition between 'upwards' and 'downwards' traps, mainly in the presence of phenanthrene. This was tested on Folsomia manolachei Bagnall, which was projected far from the origin on the north (positive) side of Axis 2, more remote species being rather erratic in our samples. This species was also the main component of the collembolan community (Table 1). In the absence of phenanthrene, no difference occurred between upward and downward trapping, while upward movement was more important than downward movement in the presence of phenanthrene (Fig. 3).

\section{Discussion}

Despite the absence of any bulk effect of phenanthrene, neither on total abundance nor on sample species richness, some species among the dominant members of the community were markedly affected by the application of phenanthrene. Folsomia manolachei, an hemiedaphic species sensu Gisin (1943), was living mainly in 
1 the first top $\mathrm{cm}$ if the soil in our study site (Arpin et al., 1980), but was found deeper as

2 well in our experimental conditions (Table 1). The contrast between upward and

3 downward trapping of this species, only in the presence of phenanthrene (Fig. 3),

4 showed that this species was attracted vertically to phenanthrene. This attraction did

5 not seem to proceed at large distance, since the contrast between 'upwards' and

6 'downwards' was more due to a deficit in 'downwards' specimens than to an increase in

7 'upwards' specimens (Fig. 3). Other studies showed that F. manolachei, as well as the

8 nearby F. quadrioculata, was attracted to heavy metals such as lead (Chauvat and

9 Ponge, 2002) and copper (Filser and Hölscher, 1997; Filser et al., 2000). This, together

10 with results of the present study, may explain why this species, one of the three

11 dominant springtail species in temperate soils, the other two being Parisotoma notabilis

12 and Isotomiella minor, is absent or at least poorly represented in polluted sites

13 (Bengtsson and Rundgren, 1988; Sterzynska, 1989; Sjögren, 1997; Fountain and

14 Hopkin, 2004b), although some populations may be better adapted than others

15 (Hågvar and Abrahamsen, 1990; Chauvat and Ponge, 2002). Another common

16 species, I. minor, did not show any trend of attraction nor of avoidance to phenanthrene

17 (Table 1). Tranvik and Eijsackers (1989) demonstrated that the absence of avoidance

18 of pollutants by this species was detrimental to its survival in a metal-polluted soil.

The effect of phenanthrene on the contrast between 'horizontal' and 'vertical'

21 traps in the other hemiedaphic $L$. lanuginosus can be explained by a decrease in

22 horizontal movements of surface-living species. In our experiment, L. lanuginosus was

23 living preferentially at the soil surface (Table 1, Fig. 2). The observed decrease in

24 'horizontal' minus 'vertical' densities of this species was mostly due to a decrease in

25 'horizontal' densities (Fig. 2), whether 'inwards' or 'outwards' (Table 1). Thus the main

26 effect of phenanthrene was that fewer animals were trapped when moving horizontally

27 at or near the soil surface. Since L. lanuginosus, as most entomobryid species,

28 disperse easily (Ojala and Huhta, 2001), we can suspect that either (i) there was a 
1 decrease in the whole population due to toxic effects, (ii) animals moved more slowly at

2 the soil surface. The first hypothesis can be ruled out, since no decrease was observed

3 in 'vertical' traps. The second hypothesis is largely plausible, due to well-known

4 narcotic effects of PAHs (Still et al., 2001; Landrum et al., 2003).

5

6 5. Conclusion

7

The use of horizontal and vertical directional traps may help to better

9 understand behavioural effects of PAHs upon soil animal communities. Although no

10 effect was detected at the community level, some of the most representative species

11 responded to the application of phenanthrene at the soil surface. Folsomia manolachei,

12 an isotomid species, was attracted to phenanthrene, which may in the long-term cause

13 its local disappearance. Lepidocyrtus lanuginosus, an entomobryid species mostly

14 living at the soil surface, was mostly affected by a decrease in its dispersal rate,

15 another mechanism which may be detrimental to its long-term survival in contaminated 16 soils.

17

18 Acknowledgements

19

The present study has been undergone with a financial support from the

21 Agence de l'Environnement et de la Maitrise de l'Énergie (ADEME), which is greatly acknowledged.

References 
1 Arpin, P., Kilbertus, G., Ponge, J.F., Vannier, G., 1980. Importance de la microflore et

Bengtsson, G., Erlandsson, A., Rundgren, S., 1988. Fungal odour attracts soil Collembola. Soil Biology and Biochemistry 20, 25-30.

Bengtsson, G., Hedlund, K., Rundgren, S., 1991. Selective odor properties in the soil Collembola Onychiurus armatus. Journal of Chemical Ecology 17, 2113-2125.

Bengtsson, G., Rundgren, S., 1988. The Gusum case: a brass mill and the distribution of soil Collembola. Canadian Journal of Zoology 66, 1518-1526.

Best, G.R., Nabholz, J.V., Ojasti, J., Crosssley, D.A.Jr, 1978. Response of microarthropod populations to naphthalene in three contrasting habitats. Pedobiologia 18, 189-201.

Bouchez, M., Blanchet, D., Haeseler, F., Vandecasteele, J.P., 1996. Les hydrocarbures aromatiques polycycliques dans l'environnement. I. Propriétés, origines, devenir. Revue de l'Institut Français du Petrole 51, 407-419.

Bretfeld, G., 1999. Synopses on palaearctic Collembola. II. Symphypleona. Abhandlungen und Berichte des Naturkundemuseums Görlitz 71, 1-318.

Brêthes, A., Brun, J.J., Jabiol, B., Ponge, J.F., Toutain, F., 1995. Classification of forest humus forms: a French proposal. Annales des Sciences Forestières 52, 535546. 
1 Chauvat, M., Ponge, J.F., 2002. Colonization of heavy metal-polluted soils by

Crouau, Y., Chenon, P., Gisclard, C., 1999. The use of Folsomia candida (Collembola, Isotomidae) for the bioassay of xenobiotic substances and soil pollutants. Applied Soil Ecology 12, 103-111.

Dorn, P.B., Vipond, T.E., Salanitro, J.P., Wisniewski, H.L., 1998. Assessment of the acute toxicity of crude oils in soils using earthworms, Microtox®, and plants. Chemosphere 37, 845-860.

Duelli, P., Studer, M., Marchand, I., Jakob, S., 1990. Population movement of arthropods between natural and cultivated areas. Biological Conservation 54 , 193-207.

Edwards, C.A., Fletcher, K.E., 1971. A comparison of extraction methods for terrestrial arthropods. In: Phillipson, J. (Ed.), Methods of Study in Quantitative Soil Ecology: Population, Production and Energy Flow. Blackwell, Oxford, UK, pp. 150-185.

Eijsackers, H., 1978. Side effects of the herbicide 2,4,5-T affecting mobility and mortality of the springtail Onychiurus quadriocellatus Gisin (Collembola). Zeitschrift für Angewandte Entomologie 86, 349-372.

Erstfeld, K.M., Snow-Ashbrook, J., 1999. Effects of chronic low-level PAH contamination on soil invertebrate communities. Chemosphere 39, 2117-2139. 
1 Fábián, M., Petersen, H., 1994. Short-term effects of the insecticide dimethoate on activity and spatial distribution of a soil inhabiting collembolan Folsomia fimetaria Linné (Collembola: Isotomidae). Pedobiologia 38, 289-302.

Fent, K., 2003. Ecotoxicological problems associated with contaminated sites. Toxicology Letters 140/141, 353-365.

Filser, J., Hölscher, G., 1997. Experimental studies on the reactions of Collembola to copper contamination. Pedobiologia 41, 173-178.

Filser, J., Wittmann, R., Lang, A., 2000. Response types in Collembola towards copper in the microenvironment. Environmental Pollution 107, 71-78.

Fjellberg, A., 1998. The Collembola of Fennoscandia and Denmark. I. Poduromorpha. Brill, Leiden.

Fountain, M.T., Hopkin, S.P., 2004a. Biodiversity of Collembola in urban soils and the use of Folsomia candida to assess soil ‘quality'. Ecotoxicology 13, 555-572.

Fountain, M.T., Hopkin, S.P., 2004b. A comparative study of the effects of metal contamination on Collembola in the field and in the laboratory. Ecotoxicology $13,573-587$.

Fountain, M.T., Hopkin, S.P., 2005. Folsomia candida (Collembola): a "standard" soil arthropod. Annual Review of Entomology 50, 201-222.

Gillet, S., Ponge, J.F., 2004. Are acid-tolerant Collembola able to colonise metalpolluted soil? Soil Biology and Biochemistry 26, 219-231. 
2 Gisin, H., 1943. Ökologie und Lebensgemeinschaften der Collembolen im

Greenacre, M.J., 1984. Theory and Applications of Correspondence Analysis. Academic Press, London.

Hågvar, S., Abrahamsen, G., 1990. Microarthropods and Enchytraeidae (Oligochaeta) in naturally lead-contaminated soil: a gradient study. Environmental Entomology 19, 1263-1277.

Hedlund, K., Bengtsson, G., Rundgren, S., 1995. Fungal odour discrimination in two sympatric species of fungivorous collembolans. Functional Ecology 9, 869-875.

Hopkin, S.P., 2000. A Key to the Springtails of Britain and Ireland, AIDGAP Test Version. Field Studies Council, Shrewsbury, UK.

Hopkin, S.P., Hames, C.A.C., Bragg, S., 1989. Terrestrial isopods as biological indicators of zinc pollution in the Reading area, South East England. Monitore Zoologica Italiana, Monografia 4, 477-488.

Johnson, D.L., Jones, K.C., Langdon, C.J., Piearce, T.G., Semple, K.T., 2002. Temporal changes in earthworm availability and extractability of polycyclic aromatic hydrocarbons in soil. Soil Biology and Biochemistry 34, 1363-1370. 
1 Jordana, R., Arbea, J.I., Simón, C., Luciáñez, M.J., 1997. Fauna Iberica. VIII.

Landrum, P.F., Lotufo, G.R., Gossiaux, D.C., Gedeon, M.L., Lee, J.H., 2003. Bioaccumulation and critical body residue of PAHs in the amphipod, Diporeia spp.: additional evidence to support toxicity additivity for PAH mixtures. Chemosphere 51, 481-489.

da Luz, T.N., Ribeiro, R., Sousa, J.P., 2004. Avoidance tests with Collembola and earthworms as early screening tools for site-specific assessment of polluted soils. Environmental Toxicology and Chemistry 23, 2188-2193.

Michelozzi, M., Raschi, A., Tognetti, R., Tosi, L., 1997. Eco-ethological analysis of the interaction between isoprene and the behaviour of Collembola. Pedobiologia $41,210-214$.

Ojala, R., Huhta, V., 2001. Dispersal of microarthropods in forest soil. Pedobiologia 45, 443-450.

Petersen, H., Gjelstrup, P., 1998. Effects of the insecticide dimethoate on the behaviour of Folsomia fimetaria (L.)(Collembola: Isotomidae). Applied Soil Ecology 9, 389-392.

Ponge, J.F., 1973. Application de l'analyse factorielle des correspondances à l'étude des variations annuelles dans les populations de microarthropodes. Bulletin d’Écologie 4, 319-327. 
1 Ponge, J.F., Bandyopadhyaya, I., Marchetti, V., 2002. Interaction between humus form

Ponge, J.F., Gillet, S., Dubs, F., Fedoroff, E., Haese, L., Sousa, J.P., Lavelle, P., 2003. Collembolan communities as bioindicators of land use intensification. Soil Biology and Biochemistry 35, 813-826.

Potapov, M., 2001. Synopses on Palaearctic Collembola. III. Isotomidae. Abhandlungen und Berichte des Naturkundemuseums Görlitz 73, 1-603.

Sadaka-Laulan, N., Ponge, J.F., Roquebert, M.F., Bury, E., Boumezzough, A., 1998. Feeding preferences of the collembolan Onychiurus sinensis for fungi colonizing holm oak litter (Quercus rotundifolia Lam.). European Journal of Soil Biology 34, 179-188.

Schirmer, K., Dixon, D.G., Greenberg, B.M., Bols, N.C., 1998. Ability of 16 priority PAHs to be directly cytotoxic to a cell line from the rainbow trout gill. Toxicology 127, 129-141.

Shakir Hanna, S.H., Weaver, R.W., 2002. Earthworm survival in oil contaminated soil. Plant and Soil 240, 127-132.

Sjögren, M., 1997. Dispersal rates of Collembola in metal polluted soil. Pedobiologia 41, 506-513. 
1 Sterzynska, M., 1989. Collembola from urban areas (Warsaw, Poland). In: Dallai, R.

Still, K.R., Alexander, W.K., Nordholm, A.F., Wilson, C.L., Rossi III, J., 2001. A review of the neurotoxicity risk of selected hydrocarbon fuels. Journal of Toxicology and Environmental Health, Part B, Critical Reviews 4, 223-312.

Tranvik, L., Eijsackers, H., 1989. On the advantage of Folsomia fimetarioides over Isotomiella minor (Collembola) in a metal polluted soil. Oecologia 80, 195-200.

Vannier, G., 1970. Réactions des microarthropodes aux variations de l'état hydrique du sol. In: Vannier, G. (Ed.), Réactions des microarthropodes aux variations de l'état hydrique du sol. Techniques relatives à l'extraction des arthropodes su sol. CNRS, Paris, pp. 23-258.

Visser, S., Whittaker, J.B., 1977. Feeding preferences for certain litter fungi by Onychiurus subtenuis (Collembola). Oikos 29, 320-325.

Yeardley, R.B.Jr, Lazorchak, J.M., Gast, L.C., 1996. The potential of an earthworm avoidance test for evaluation of hazardous waste sites. Environmental Toxicology and Chemistry 15, 1532-1537.

Zimdars, B., Dunger, W., 1994. Synopses on Palaearctic Collembola. I. Tullbergiinae. Abhandlungen und Berichte des Naturkundemuseums Görlitz 68, 1-71. 


\section{Figure captions}

3 Fig. 1. Correspondence analysis. Projection of active (collembolan species) and passive (treatments, population data) variables in the plane of the first two factorial axes. Variables were duplicated, except treatment variables (see text for further explanation). Higher values of each variable are indicated in bold roman, lower values in italic type. For the sake of clarity, only higher values of springtail species are shown (lower values are symmetrical of higher values around the origin of the axes)

Fig. 2. Lepidocyrtus lanuginosus in directional traps. Comparison between 'horizontal' and 'vertical' traps. Values are the sum of two conjugated (inverted) boxes, averaged over five replicates, with standard error of the means. Comparisons between both groups were done by paired t-test. ${ }^{* *}=$ significant departure from null hypothesis at 0.001 level

Fig. 3. Folsomia manolachei in directional traps. Comparison between 'upward' and 'downward' animals trapped in 'vertical' traps. Values are means of five replicates, with standard errors. Comparisons between both groups were done by paired t-test. ${ }^{* *}=$ significant departure from null hypothesis at 0.01 level 
Table 1. Mean density and species richness of Collembola in horizontal and vertical directional traps, in the presence or absence of phenanthrene. Values are means of 5 replicates, followed by standard errors

\begin{tabular}{|c|c|c|c|c|c|c|c|c|c|}
\hline & & \multicolumn{4}{|c|}{ Phenanthrene } & \multicolumn{4}{|c|}{ Control } \\
\hline & & Inwards & Outwards & Downwards & Upwards & Inwards & Outwards & Downwards & Upwards \\
\hline$\overline{\mathrm{AFU}}$ & Allacma fusca & $0.6 \pm 0.2$ & $1.6 \pm 0.2$ & $0.6 \pm 0.2$ & $0.6 \pm 0.6$ & $0.6 \pm 0.2$ & $1 \pm 0$ & $0.8 \pm 0.4$ & $0.4 \pm 0.2$ \\
\hline $\mathrm{CDE}$ & Ceratophysella denticulata & 0 & 0 & 0 & 0 & 0 & 0 & 0 & $0.2 \pm 0.2$ \\
\hline DTI & Desoria tigrina & 0 & $0.2 \pm 0.2$ & $0.2 \pm 0.2$ & $0.4 \pm 0.2$ & 0 & 0 & 0 & 0 \\
\hline DSP & Deuterosminthurus sp. & $0.2 \pm 0.2$ & 0 & 0 & 0 & 0 & $0.2 \pm 0.2$ & $0.2 \pm 0.2$ & 0 \\
\hline DFU & Dicyrtoma fusca & $1.8 \pm 0.6$ & $1 \pm 0.4$ & $0.6 \pm 0.2$ & $1.4 \pm 0.7$ & $1 \pm 0.6$ & $3.2 \pm 0.9$ & $1.2 \pm 0.4$ & $1.2 \pm 0.4$ \\
\hline EAL & Entomobrya albocincta & 0 & $0.2 \pm 0.2$ & 0 & 0 & 0 & 0 & 0 & 0 \\
\hline FMA & Folsomia manolachei & $61.6 \pm 9.8$ & $57.8 \pm 7.4$ & $33.4 \pm 4.6$ & $56.8 \pm 3.8$ & $50.8 \pm 5.7$ & $65 \pm 7.9$ & $54.8 \pm 11.8$ & $50.6 \pm 5.7$ \\
\hline FTR & Friesea truncata & $4.4 \pm 1$ & $1.8 \pm 0.2$ & $2.6 \pm 0.5$ & $2 \pm 0.7$ & $2.4 \pm 1.7$ & $2.6 \pm 0.9$ & $2.6 \pm 0.7$ & $3 \pm 1.3$ \\
\hline HMA & Heteromurus major & $4 \pm 1.9$ & $1.4 \pm 0.5$ & $1 \pm 0.3$ & $0.8 \pm 0.4$ & $4 \pm 1.6$ & $2.2 \pm 0.8$ & $0.2 \pm 0.2$ & $0.2 \pm 0.2$ \\
\hline $\mathrm{HNI}$ & Heteromurus nitidus & $0.2 \pm 0.2$ & 0 & 0 & $0.2 \pm 0.2$ & 0 & 0 & 0 & $0.2 \pm 0.2$ \\
\hline IMI & Isotomiella minor & $10.2 \pm 4.6$ & $13.4 \pm 3.6$ & $21 \pm 10.7$ & $18.2 \pm 6.2$ & $7.8 \pm 1.3$ & $11.2 \pm 4.2$ & $14.8 \pm 4.1$ & $24.4 \pm 9$ \\
\hline KBU & Kalaphorura burmeisteri & $0.2 \pm 0.2$ & $0.2 \pm 0.2$ & $2.2 \pm 0.6$ & 0 & $0.4 \pm 0.2$ & $0.2 \pm 0.2$ & $1.2 \pm 0.5$ & 0 \\
\hline LCU & Lepidocyrtus curvicollis & 0 & 0 & 0 & $0.2 \pm 0.2$ & $0.4 \pm 0.2$ & $0.2 \pm 0.2$ & 0 & 0 \\
\hline LCY & Lepidocyrtus cyaneus & $2.2 \pm 0.9$ & $1.6 \pm 0.9$ & $2 \pm 0.9$ & $0.4 \pm 0.4$ & $1.8 \pm 0.6$ & $1.8 \pm 0.4$ & $0.2 \pm 0.2$ & 0 \\
\hline LLA & Lepidocyrtus lanuginosus & $36.4 \pm 8.5$ & $37.8 \pm 7.4$ & $20.6 \pm 1.4$ & $13.4 \pm 2.5$ & $50.2 \pm 6.8$ & $49.8 \pm 5.5$ & $17.4 \pm 3.7$ & $10.6 \pm 3.5$ \\
\hline MIT & Mesaphorura italica & $0.4 \pm 0.2$ & $0.6 \pm 0.4$ & $0.2 \pm 0.2$ & $0.4 \pm 0.2$ & 0 & 0 & 0 & $0.4 \pm 0.4$ \\
\hline MKR & Mesaphorura krausbaueri & $0.2 \pm 0.2$ & $0.2 \pm 0.2$ & 0 & $0.2 \pm 0.2$ & $0.2 \pm 0.2$ & 0 & $0.2 \pm 0.2$ & 0 \\
\hline MPY & Micranurida pygmaea & 0 & 0 & 0 & 0 & 0 & $0.2 \pm 0.2$ & 0 & 0 \\
\hline MSE & Micranurida sensillata & 0 & 0 & $0.2 \pm 0.2$ & 0 & 0 & 0 & 0 & $0.6 \pm 0.2$ \\
\hline MGR & Monobella grassei & $0.2 \pm 0.2$ & $0.4 \pm 0.2$ & 0 & 0 & $0.2 \pm 0.2$ & $0.2 \pm 0.2$ & 0 & 0 \\
\hline NMU & Neanura muscorum & 0 & 0 & $0.6 \pm 0.6$ & 0 & $0.2 \pm 0.2$ & 0 & 0 & 0 \\
\hline OCR & Oncopodura crassicornis & 0 & 0 & 0 & 0 & 0 & 0 & $0.2 \pm 0.2$ & 0 \\
\hline OPS & Onychiurus pseudogranulos & $10.4 \pm 2.2$ & $7.8 \pm 1.1$ & $3.2 \pm 0.8$ & $4 \pm 1.2$ & $10.2 \pm 0.9$ & $13.2 \pm 3.7$ & $3.2 \pm 1.2$ & $7 \pm 3.5$ \\
\hline PCA & Paratullbergia callipygos & $1.4 \pm 0.5$ & $0.8 \pm 0.4$ & $0.2 \pm 0.2$ & $0.6 \pm 0.2$ & $0.4 \pm 0.2$ & $0.4 \pm 0.2$ & $0.4 \pm 0.4$ & $1.2 \pm 0.6$ \\
\hline PNO & Parisotoma notabilis & $51.2 \pm 10.5$ & $48 \pm 5.8$ & $55.4 \pm 10.7$ & $76.6 \pm 15.1$ & $43.6 \pm 6.8$ & $41.6 \pm 3.1$ & $57.8 \pm 12.9$ & $69 \pm 7.2$ \\
\hline PPA & Pseudachorutes parvulus & $1.2 \pm 0.4$ & $2 \pm 0.7$ & $0.2 \pm 0.2$ & $0.2 \pm 0.2$ & $2.2 \pm 1.7$ & $0.6 \pm 0.2$ & $0.4 \pm 0.2$ & $0.6 \pm 0.6$ \\
\hline PSE & Pseudisotoma sensibilis & 0 & 0 & 0 & $0.2 \pm 0.2$ & 0 & 0 & 0 & 0 \\
\hline PAL & Pseudosinella alba & $2.6 \pm 1.2$ & $4 \pm 1.4$ & $2.4 \pm 0.5$ & $7.6 \pm 3.6$ & $1.4 \pm 0.6$ & $4.4 \pm 2.2$ & $2.6 \pm 0.7$ & $4.2 \pm 2.3$ \\
\hline PIM & Pseudosinella immaculata & $0.4 \pm 0.2$ & $0.2 \pm 0.2$ & $0.4 \pm 0.2$ & 0 & 0 & 0 & $0.6 \pm 0.2$ & $0.4 \pm 0.2$ \\
\hline SAU & Sminthurinus aureus & $6 \pm 0.8$ & $4.4 \pm 1.4$ & $2.2 \pm 1$ & $0.8 \pm 0.4$ & $8 \pm 1.5$ & $9 \pm 1.4$ & $2.4 \pm 0.5$ & $1 \pm 0.6$ \\
\hline SPU & Sphaeridia pumilis & $15.4 \pm 2.9$ & $10.2 \pm 1.9$ & $6.4 \pm 1.9$ & $6 \pm 1.9$ & $15.2 \pm 2$ & $16.4 \pm 3.3$ & $9.4 \pm 1.4$ & $6.4 \pm 2.4$ \\
\hline SDE & Stenaphorura denisi & 0 & $0.2 \pm 0.2$ & 0 & $0.4 \pm 0.2$ & $0.4 \pm 0.2$ & 0 & $0.2 \pm 0.2$ & $0.4 \pm 0.2$ \\
\hline WPO & Wankeliella pongei & 0 & 0 & 0 & $0.2 \pm 0.2$ & 0 & 0 & 0 & 0 \\
\hline & Total abundance & $211.2 \pm 28.7$ & $195.8 \pm 15.7$ & $155.6 \pm 20.7$ & $191.6 \pm 27.6$ & $201.4 \pm 13.3$ & $223.4 \pm 5.5$ & $170.8 \pm 19.6$ & $182 \pm 22$ \\
\hline & Sample species richness & $15.4 \pm 0.7$ & $15.2 \pm 0.4$ & $14.2 \pm 0.4$ & $13.2 \pm 0.6$ & $13.6 \pm 0.5$ & $14.4 \pm 0.4$ & $13.2 \pm 0.9$ & $12.2 \pm 0.9$ \\
\hline
\end{tabular}




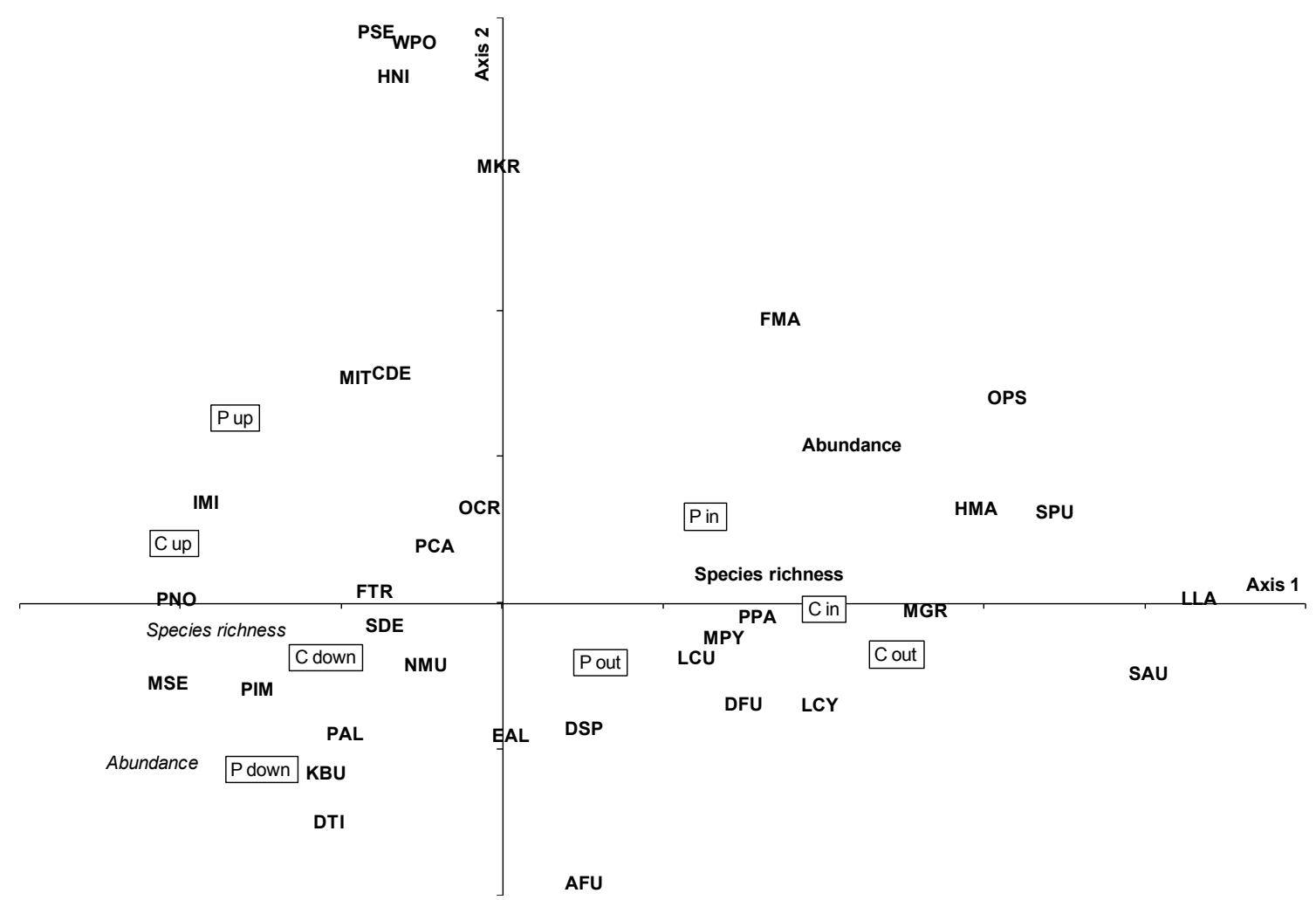

2 Fig. 1

3 


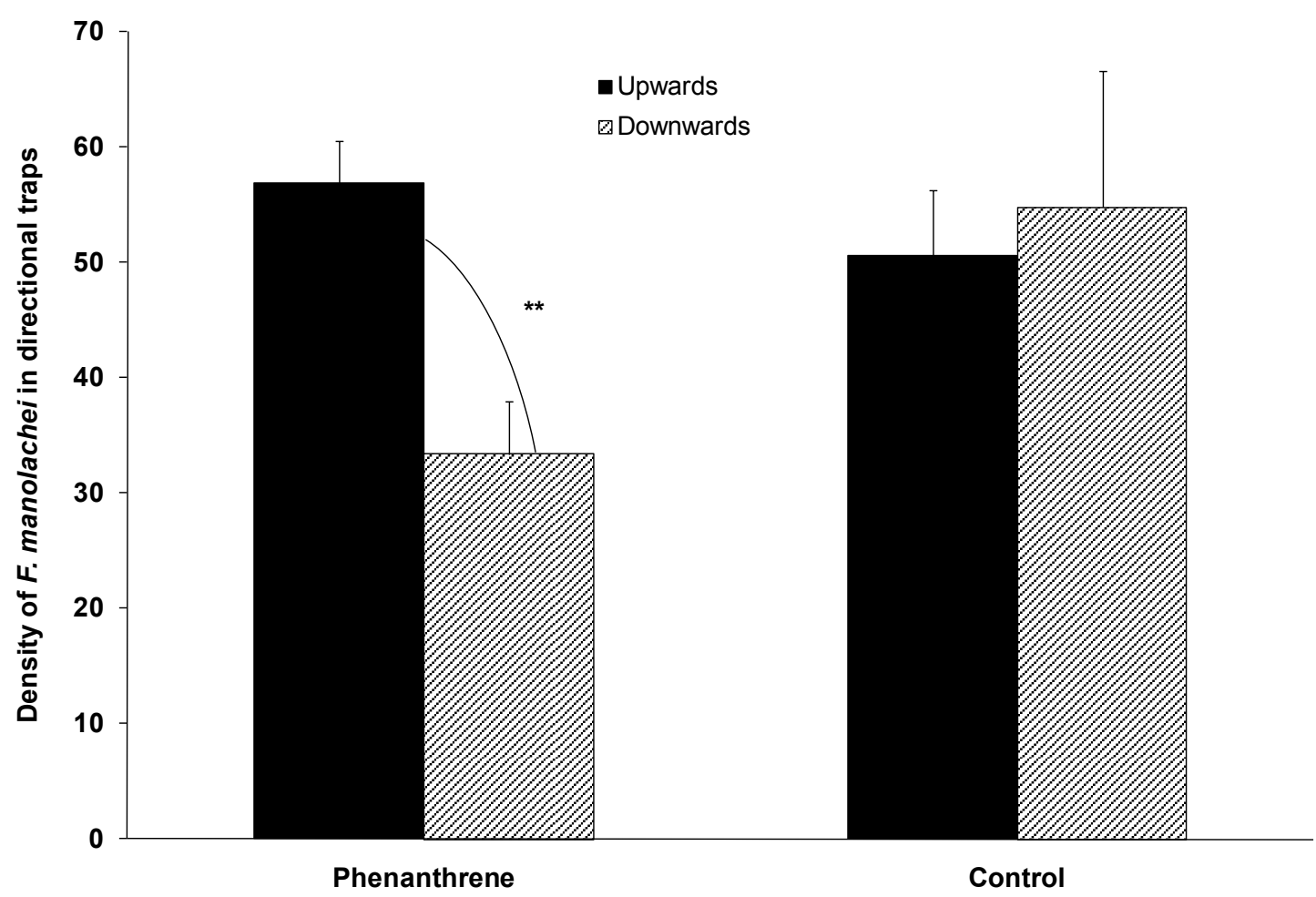

2 Fig. 2 


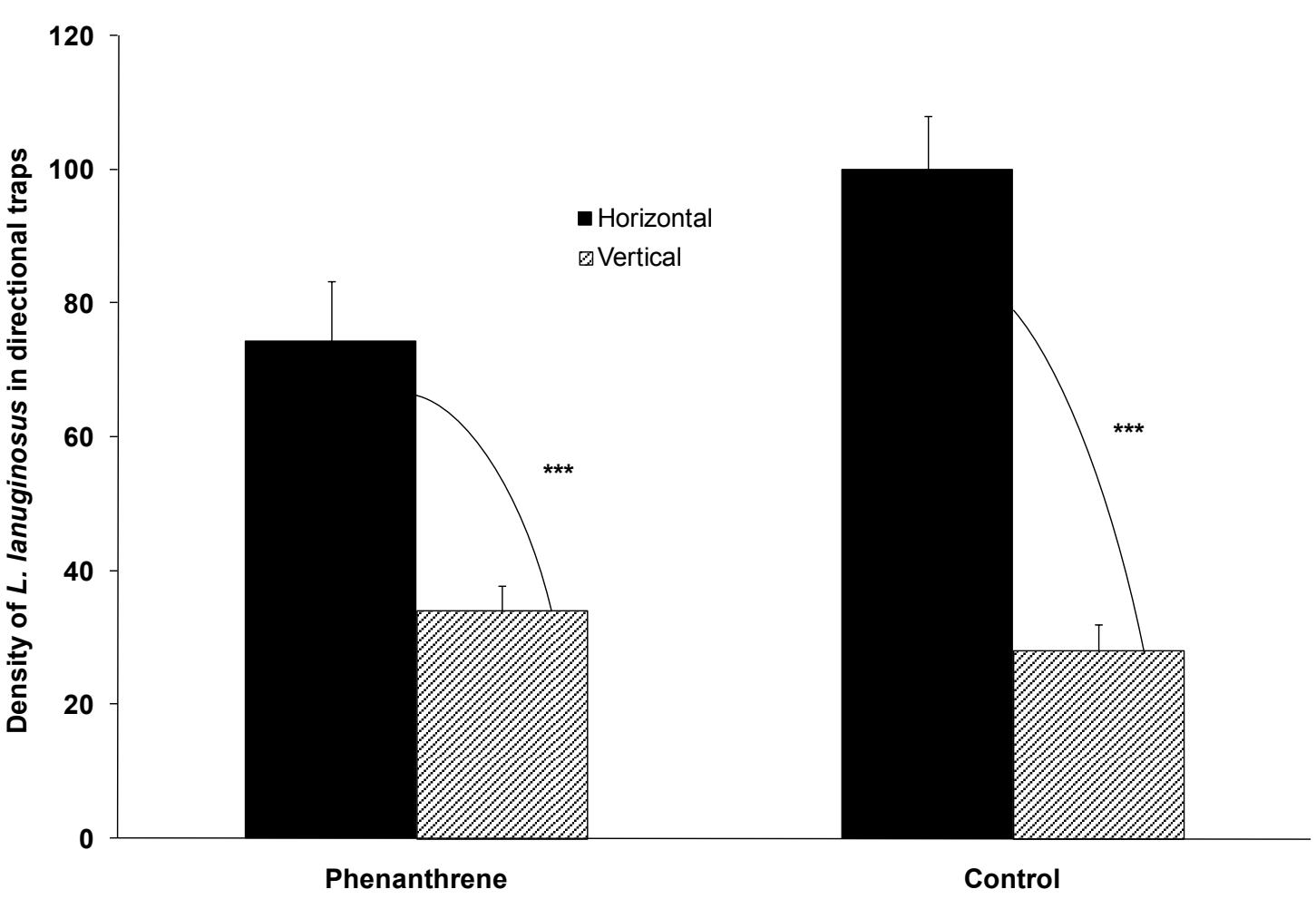

$2 \quad$ Fig. 3 